\title{
Selecting Third-Party Reverse Logistics Service Providers: A Case of Consumer Packaged Goods Enterprises in Hanoi
}

\author{
Dao Minh $\mathrm{ANH}^{1^{*}}$ and Nguyen The TRUNG ${ }^{2}$ \\ ${ }^{1}$ Faculty of Business Administration, Foreign Trade University, Hanoi, Vietnam \\ ${ }^{2}$ Esquel Group, Hanoi, Vietnam \\ "Corresponding author: $\underline{\text { anhdm@ftu.edu.vn }}$
}

\begin{abstract}
Research purpose:

This paper aims to find out the factors that affect to decisions of choosing 3PLRLs of CPG enterprises.
\end{abstract}

Research motivation:

Recently, there has been a boosting interest in reverse logistics resulting from many reasons such as (1) the incredible growth of E-commerce due to Covid-19 pandemic; or (2) Economic growth, population boom, higher living standard requirements and shortened product life cycles, and the like. Among many controversial in reverse logistics, the interest in the consume-packaged goods (CPG) industry is in the intensive focus of researchers and managers. However, the consumer-packaged goods industry (CPG), whose reverse logistics flow plays such a crucial role as hasn't been done much by Vietnamese researchers. Research related to reverse logistics in Vietnam mainly stops at mentioning the perspective of state solid waste management in terms of legislation, planning and recycling technology.

Research design, approach, and method:

The research applies both qualitative and quantitative research to examine the reliability of the design research model. Survey data were gathered from a sample of 200 respondents. Structural equation modeling was used to test the hypothesized relationships.

\section{Main findings:}

Findings revealed that 5 main factors including Total cost, Quality of service, Credibility, Tangibility, and Eco-sustainability have positive impacts on the selection of $3 P L R L s$ at CPG enterprises.

Practical/managerial implications:

The results of the research will be very helpful for 3PLRLs firms to enhance their service and capacity to serve and meet the demand of CPG enterprises.

Keywords: video-sharing, online video, on-sharing, viral video, viral marketing, emotion, and behavior. 


\section{INTRODUCTION}

The burgeoning complexity of logistics due to fast-growing hi-technologies, changing customer expectations and the ongoing quest to develop greater business resilience during Covid-19 pandemic has led to an uptick in outsourced activities (Wollenhaupt, 2021). Despite not being an unpopular practice, outsourcing the logistics network to a third-party organization is still viewed as a critical strategic decision since $55 \%$ of outsourcing decisions turn out a failure after only three to five years (Tsai, et. al., 2012). A wrong logistics outsourcing strategy could obviously bring about a multitude of corporate problems resulting in increased logistics and operations expenditure as well as affecting the company's competitive advantage against direct competitors and brand image (de Mello Bandeira, et. al., 2011).

Over the past few years, there has been a boosting interest in reverse logistics resulting from many reasons. The incredible growth of E-commerce due to Covid-19 pandemic recently has sent returns skyrocketing. Economic growth, population boom, higher living standard requirements and shortened product life cycles lead to the remarkable rise in the number of products that need to be reused, recycled as well as the waste required to be appropriately treated (World Bank Group - International Development, Poverty, \& Sustainability, 2021). In addition, more and more governments and business entities alike are having growing concern with environmental sustainability and corporate social responsibility (CSR) apart from economic profit gains which can be resolved efficiently with a proper reverse logistics process.

The interest in reverse logistics and the urgency for its implementation is at the uppermost level in the consumer-packaged goods (CPG) industry. CPG industry is believed to be the biggest contributor to the packaging plastic footprint generated in the world (Infographic: Worst Plastic Polluters in 2020, 2021). "Take, make, waste" is no longer an acceptable and sustainable way of operating to survive in the consumer-packaged goods (CPG) industry while consumer's buying decisions are not only made in terms of reasonable cost but the environmentally friendly brand image (Plastic Pollution and CPG Industry, 2021).

Reverse logistics in Vietnam is still a relatively new concept. Research related to reverse logistics in Vietnam mainly stops at mentioning the perspective of state solid waste management in terms of legislation, planning and recycling technology. The number of direct studies on reverse logistics is not many and only puts the attention on electronic products, plastics, and second-hand household appliances. However, the consumer-packaged goods industry (CPG), whose reverse logistics flow plays such a crucial role as hasn't been done much by Vietnamese researchers. So, this paper aims to find out the factors that affect to the selection of 3PLRLs at CPG enterprises in Hanoi. From the results, the 3PLRLs can learn how CPG enterprises choose 3PLRLs' services, since then, 3PLRLs can enhance their services to meet the requirement of $\mathrm{CPG}$ enterprises. After the introduction, there will be literature review, research methodology, research results, general assessment, recommendations, and conclusion and further research.

\section{LITERATURE REVIEW}

\subsection{Third-party reverse logistics service provider (3PLRLs)}

According to the Council of Supply Chain Management Professionals (CSCMP), reverse logistics is "the process of planning, implementation, and controlling the cost-efficient and cost-effective system of raw materials, in-process inventory, finished stocks and related data information from the consumption point to the origin point for the purpose of recapturing existed value or proper disposition" (Council of Supply Chain Management Professionals, 2021).

Council of Supply Network Management Professionals (CSMCP) characterized a 3PL as "a business providing with numerous logistics services for usage by consumers." The provider ideally merges or "bundles" these services together. These companies make it easier for parts and materials to get from suppliers to plants, as well as finished goods to get from plants to distributors and retailers."

\subsection{Overview of consumer-packaged goods (CPG) industry}

Consumer packaged goods or CPG industry offers products that are typically low-cost commodities that sell quickly. Because it has a shorter shelf life, it attracts a greater demand from consumers. This category of products has a high volume of sales but a poor profit margin. The Consumer-Packaged Goods Industry is one of the most competitive in the world. Some of the leading players of the CPG global market include Nestlé, J\&J, Procter \& Gamble (P\&G), Unilever, etc. CPG industry is also considered to be the fastest growing. According to the most cautious forecasts, the worldwide Consumer Packaged Goods (CPG) market size would rise by 20 percent year over year in 2021(Global Customer Packaged Goods (CPG) Market Size, Shares, Value, and Competitive Landscape 2024, 2021). Another characteristic of the CPG industry is vulnerability. The COVID-19 pandemic has put an enormous burden on the consumer-packaged goods (CPG) business, and the consequences are expected to last until 2022

\subsection{Previous empirical research on criteria in selecting third-party reverse logistics service provider (3PLRLs)}

In global scale, there has been several of studies 
examining on factors to select third-party reverse logistics service providers (3PLRLs). Research by Rostamzadeh et. al. (2020) provides a framework for evaluating 3PLRLs and then design a method in a fuzzy environment. The main criteria were ranked as follows: "geographical location" $\mathrm{C} 1$, "RL process function" $\mathrm{C} 2$, "organizational and business measurement" C3, "strategical org role of RL" C4, "IT system and communicating" $\mathrm{C} 5$, "general entrepreneur consideration" C6, "product lifecycle position" C7. Research by Tajika, Azadniab, Azanizawati Ma'aramc and Hassand develops a hybrid "fuzzy multiple-attribute decision making” (FMCDM) methodology for choosing 3PLRLs. Environmental factor was given the most weight among three factors with 0.4344 and proved to have the most impacts on the 3PLs selection decisions.

Research by Le et. al. (2014) explored a model of factors impacting the 3PLs selection choice of firms working in the exporting and importing sectors in the south of Vietnam in general and in Ho Chi Minh city. "Responsiveness of service", "Reliability", "Assurance", "Tangibility", "Sympathy \& Empathy", and "Service price" are the model's six major components. It is clear to see the need arises for a research on criteria to make evaluation on the third-party reverse logistics service provider selection so that entrepreneurs could ensure effective reverse logistics implementation of the enterprises in Vietnam.

\section{RESEARCH METHODOLOGY}

\subsection{Research model and hypotheses}

The authors decided to propose a model including 5 factors that have impacts on CPG entrepreneurs' decisions on the choice of third-party reverse logistics service providers (3PLRLs) in Hanoi. Generally, these factors are "Total cost", "Quality of service", "Credibility", "Tangibility", and "Eco-sustainability".

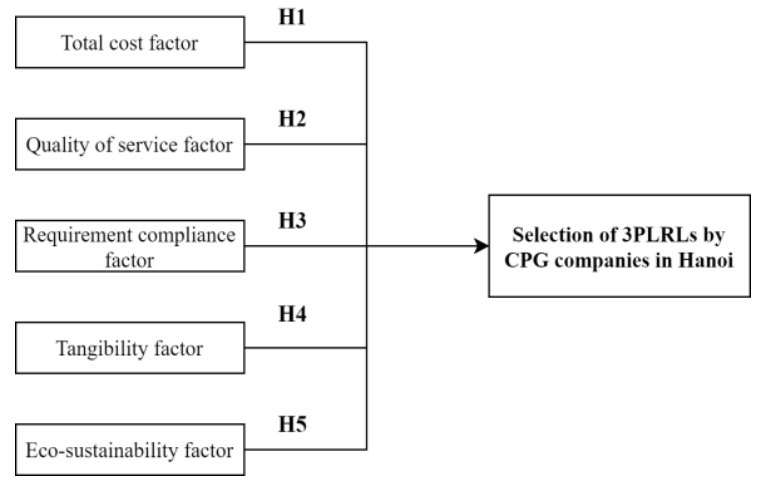

"Total cost" means all the expenses to perform activities including warehouse and distribution management, stock management, order processing, packing, transferring and distributing, technology enhancement and maintenance and IT management in the reverse logistics flows (Coşkun, 2017). Reverse logistics costs, according to a wider definition offered by Le, et.al. (2014) are made up of cost elements ranging from material procurement through sales, distribution, and after-sales services, and include shipping, delivering delays, customs clearance, interim transit, storing, degradation, disposal, insurance, damage, systems engineering, and information technology, etc. So, the authors choose H1: Total cost has positive impacts on the decision of selecting a third-party reverse logistics service provider (3PLRLs) of consumer-packaged goods enterprises (CPG) in Hanoi.

Most prior researches have shown that indications of quality include the rate of punctual delivery, rate of damage, conversion rate, as well as 3PLRLs' quality interest, inspection and disposition processes (Gunasekaran et al, 2001; Le, et.al., 2014). So, the authors choose H2: Quality of service has positive impacts on the decision of selecting a third-party reverse logistics service provider (3PLRLs) of consumer-packaged goods enterprises (CPG) in Hanoi.

Credibility relates to ensuring that the 3PLRLs offer data transparency such as correct documentation process and reports, as well as a positive reputation and effective risk management (Zarbakhshnia et. al., 2018). Furthermore, according to Govindan et. al. (2009), willingness, resilience and inclination are also sub-factors of the credibility factor. So, the author chooses H3: Credibility has positive impacts on the decision of selecting a third-party reverse logistics service provider (3PLRLs) of consumer-packaged goods enterprises (CPG) in Hanoi.

Tangibility encompasses both physical and non-physical resources, such as warehouses, means of transportation, and handling equipment (Banomyong, et al., 2011). Additionally, with the great penetration in the business and industrial sector of the industrial revolution 4.0, the 3PLRLs company's use of information hi-technology and automation system is thought to make a significant contribution to their tangibility index (Le, et. al., 2014). So, the authors choose H4: Tangibility has positive impacts on the decision of selecting a third-party reverse logistics service provider (3PLRLs) of consumer-packaged goods enterprises (CPG) in Hanoi.

The notion of 'eco-sustainability development' is directly tied to recovery, reusing and recycling, which are parts of the aspects of reverse logistics flows (Bulut and Deran, 2008). In terms of sustainability, RL is defined as "a business strategic decision that functions as the triggering force of successfully putting recovery actions in motion in order to enhance sustainability" (Ayvaz et. al., 2015). A firm with properly eco-friendly operations is preferred by customers. So, the author chooses H5: Eco-sustainability has positive impacts on the decision of selecting a third-party reverse logistics service provider (3PLRLs) of consumer-packaged goods enterprises (CPG) in Hanoi. 


\subsection{Questionnaire and scale development}

The scales are based mainly on the author's reference to previous works of study such as Tajik, et. al. (2013), Le, et. al., (2014), Rostamzadeh et. al. (2020). The authors also make valuable adjustments to these scales with the consultation of five supply chain managers and supervisors from consumer-packaged goods sectors via in-depth interview.

The primary component of the questionnaire that the authors give out is built on a 5-point Likert type scale to determine the respondents' degree of agreement with mentioned statements, with each score denoting from 1-point means "Totally Disagree", 2-point means "Disagrees", 3-point means "Neutral", 4-point means "Agrees", and 5-point means "Absolutely Agree".

\subsection{Data collection and analysis}

\subsubsection{Data collection}

The authors collect primary data from the supply chain managers of the $\mathrm{CPG}$ production and distribution companies selected for this thesis in the study sample. The approach is a well-constructed questionnaire. Due to the social distancing issues resulting from Covid-19 pandemic, the authors will only use online platforms to distribute the questionnaire such as E-mail, Linkedin, Facebook, etc. The period for collecting the primary data is around three months which are between April 2021 and June 2021

After distributing 503 surveys via online channels to supply chain managers in CPG companies in Hanoi, the authors received 204 responses in total. Four responses were unqualified and eliminated. 200 responses were qualified and imported to Excel version 2019 for further analysis.

\subsubsection{Data analysis}

The authors uses SPSS Statistics version 22 software and Microsoft Office Excel version 2019 for data. Test and analysis methods will be conducted in a fixed sequence to ensure the accuracy: Cronbach's Alpha coefficient, EFA analysis, multiple linear regression analysis to find out the factors affecting the selection of 3PLRLs at CPG enterprises.

\section{RESEARCH RESULT}

\subsection{Result description}

As can be seen from Table 1,53.5\% of the respondents are male while female respondents accounts for $46.5 \%$. The statistics also reveals that most of the respondents has been working in supply chain function of the consumers packaged goods industry for between 3 and 5 years (56\%), while $25.5 \%$ have an over-5-year experience in this industry and no respondents are fresh or junior to supply chain in CPG companies. Most of the companies that the respondents are currently working for has been operating in Vietnam for from 5 years to 10 years, $9.5 \%$ working for companies that run in Vietnam for 1 to 3 years, $14 \%$ working for companies having 3 years to 5 years of operations, $12 \%$ working for companies operating over 10 years in Vietnam and no companies under 1 year of operations are recorded.

Table 1. Demographic data of the respondents

\begin{tabular}{lll}
\hline Characteristics & Frequency & Percentage \\
\hline Gender & 107 & \\
\hline Male & 93 & $53.5 \%$ \\
\hline Female & 0 & $46.5 \%$ \\
\hline Years of experience in CPG's supply chain field & & \\
\hline Less than 1 year & 37 & $18.5 \%$ \\
\hline From 1 year to 3 years & 112 & $56.0 \%$ \\
\hline From 3-5 years & 51 & $25.5 \%$ \\
\hline Over 5 years & 0 & \\
\hline Company's years of operations in Vietnam & 19 & $0 \%$ \\
\hline Less than 12 months & 28 & $9.5 \%$ \\
\hline From 1 year to 3 years & 129 & $14.0 \%$ \\
\hline From 3 years to 5 years & 24 & $64.5 \%$ \\
\hline From 5 years to 10 years & 19 & $12.0 \%$ \\
\hline Over 10 years & 68 & \\
\hline Frequency of RL service usage (a month interval) & $9.5 \%$ \\
\hline Under 7 times & 104 & $34 \%$ \\
\hline From 7 times to 30 times & 9 & $52 \%$ \\
\hline From 30 times to 60 times & $4.5 \%$ \\
\hline Over 60 times & & \\
\hline
\end{tabular}

(Synthesized by the authors, 2021) 
Table 2 clearly illustrates the descriptive statistics of independent variables of the research. It is easy to see that Tangibility factor and Quality of service factor are at the highest ranking in terms of mean. Tangibility factor (TG) has the mean of 3.51 and Quality of service (QS) are 3.50 on average. This fact indicates that CPG managers do not significantly prioritize a specific factor when choosing a 3PL for their reverse logistics activities. While the lowest mean of all variables is Eco-sustainability factor (ES) which is 3.22. Most of the standard deviation is below or around 1 except for QS1, QS4 and ES4. It may be in brief derived from the survey's respondents that the evaluated variables in the questionnaire exhibit a moderate degree of agreement.

\subsection{Cronbach's Alpha coefficient reliability analysis test}

The Cronbach's Alpha result of all factors are greater than 0.6, therefore, these scales are reliable enough for further analysis. In theses 5 scale, there are 28 independent variables whose corrected item-total correlation is all exceeding the threshold of 0.3 (Hair, et. al., 2014) and the Cronbach's alpha case when item is deleted is all below the Cronbach's Alpla of the overal variables. So Total cost (TC1, TC2, TC3, TC4,
TC5, TC6), Quality of service (QS1, QS2, QS3, QS5, QS6, QS7), Credibility (RC1, RC2. RC3, RC4), Tangibility (TG1, TG2, TG3, TG4), Eco-sustainability (ES1, ES2, ES4, ES5) and Choice of third-party reverse logistics service providers (FS3PLRL1, FS3PLRL2, FS3PLRL3, FS3PLRL4) are remained in the research model.

\subsection{Exploratory Factor Analysis (EFA)}

Concerning the Barrlett's Testing of Sphericity, the Significance of the conducted test is 0.000 which is much lower than 0.05. Concurrently, the Kaizer-Meyers-Olkin (KMO) coefficient of the conducted test reaches 0.836 which satisfies the given requirements that this figure must fall in the range between 0.50 and 1.00. The factor analysis, therefore, conforms to the research data. Also, the cumulative total variance receives the result at $69.434 \%$ which meets the criterion of exceeding $50 \%$ and the stop point's Eigenvalue is 1.623 beyond 1, indicating that the variables are statistically significant (Table 3 ).

From Table 4, it is noticeable to see that all sub-variables are grouped accurately within the factors that are initially determined.

Table 2. Descriptive statistics/ Cronbach's Alpha reliability test

\begin{tabular}{|c|c|c|c|c|c|}
\hline Variables & & Mean & Std. & $\begin{array}{l}\text { Correcte } \\
\text { d } \\
\text { Item-Tot } \\
\text { al } \\
\text { Correlati } \\
\text { on } \\
\end{array}$ & $\begin{array}{l}\text { Cronbac } \\
\text { h's } \\
\text { Alpha if } \\
\text { Item } \\
\text { Deleted }\end{array}$ \\
\hline & TC (Total cost). & \multicolumn{3}{|c|}{ Cronbach's Alpha: 0.867} & \\
\hline TC1 & $\begin{array}{l}\text { 3PLRLs company charges a competitive price for } \\
\text { reverse logistics service }\end{array}$ & 3.27 & 0.849 & 0.609 & 0.853 \\
\hline TC2 & $\begin{array}{l}\text { 3PLRLs company maintains an non-volatile reverse } \\
\text { logistics service price }\end{array}$ & 3.20 & 0.876 & 0.684 & 0.840 \\
\hline TC3 & $\begin{array}{l}\text { 3PLRLs company offers a clear price quote for reverse } \\
\text { logistics services with no hidden or vague fees. }\end{array}$ & 3.30 & 0.93 & 0.711 & 0.835 \\
\hline TC4 & $\begin{array}{l}\text { 3PLRLs company offers a simple payment } \\
\text { mechanism and payment errors do not occur. }\end{array}$ & 3.20 & 0.716 & 0.697 & 0.841 \\
\hline TC5 & $\begin{array}{l}\text { 3PLRLs company offers occasional promotion } \\
\text { program of cost reduction for reverse logistics } \\
\text { services. }\end{array}$ & 3.25 & 0.935 & 0.732 & 0.831 \\
\hline TC6 & $\begin{array}{l}\text { 3PLRLs company allows lengthy payment terms for } \\
\text { reverse logistics service. }\end{array}$ & 3.50 & 0.908 & 0.567 & 0.861 \\
\hline \multicolumn{2}{|c|}{ QS (Quality of service). } & \multicolumn{3}{|c|}{ Cronbach's Alpha: 0.875} & \\
\hline QS1 & $\begin{array}{l}\text { 3PLRLs company always implement reverse logistics } \\
\text { in an accurate manner (no damage, right amount, etc) }\end{array}$ & 3.80 & 1.195 & 0.764 & 0.841 \\
\hline QS2 & $\begin{array}{l}\text { 3PLRLs company always implement reverse logistics } \\
\text { order on time }\end{array}$ & 3.60 & 1.032 & 0.770 & 0.842 \\
\hline QS3 & 3PLRLs company always reacts proactively and fast to & 3.48 & 1.007 & 0.801 & 0.839 \\
\hline
\end{tabular}




\begin{tabular}{|c|c|c|c|c|c|}
\hline \multirow[b]{2}{*}{ QS4 } & \multicolumn{5}{|l|}{ reverse logistics order and requirements. } \\
\hline & $\begin{array}{l}\text { 3PLRLs company always understand customer's } \\
\text { insight and diversify the service menu. }\end{array}$ & 3.36 & 1.212 & 0.122 & 0.927 \\
\hline QS5 & $\begin{array}{l}\text { 3PLRLs company always provides clients with proper } \\
\text { support in an immediate way. }\end{array}$ & 3.60 & 1.134 & 0.841 & 0.831 \\
\hline QS6 & $\begin{array}{l}\text { 3PLRLs company provides customers with track \& } \\
\text { trace service }\end{array}$ & 3.48 & 1.103 & 0.853 & 0.830 \\
\hline QS7 & $\begin{array}{l}\text { 3PLRLs company has Kaizen mindset and } \\
\text { continuously improve their provided RL service. }\end{array}$ & 3.21 & 0.947 & 0.579 & 0.866 \\
\hline \multicolumn{2}{|c|}{ RC (Credibility). } & \multicolumn{3}{|c|}{ Cronbach's Alpha: 0.780} & \\
\hline RC1 & $\begin{array}{l}\text { 3PLRLs company always send back reports of reverse } \\
\text { logistics performance to the clients in a timely manner. }\end{array}$ & 3.58 & 0.772 & 0.695 & 0.693 \\
\hline $\mathbf{R C 2}$ & $\begin{array}{l}\text { 3PLRLs company always publicly or privately posts } \\
\text { holistic reverse logistics documents. }\end{array}$ & 3.41 & 0.737 & 0.687 & 0.698 \\
\hline $\mathbf{R C 3}$ & $\begin{array}{l}\text { 3PLRLs company is famous and has high rank among } \\
\text { rivals for providing good reverse logistics service. }\end{array}$ & 3.43 & 0.805 & 0.713 & 0.684 \\
\hline RC4 & $\begin{array}{l}\text { 3PLRLs company always manage uncertain risk of RL } \\
\text { flow well and quickly. }\end{array}$ & 3.43 & 0.812 & 0.604 & 0.722 \\
\hline RC5 & $\begin{array}{l}\text { 3PLRLs company's personnel always have good } \\
\text { attitude, honesty and integrity. }\end{array}$ & 3.41 & 0.881 & 0.179 & 0.865 \\
\hline \multicolumn{2}{|c|}{ TG (Tangibility). } & \multicolumn{3}{|c|}{ Cronbach's Alpha: 0.763} & \\
\hline TG1 & $\begin{array}{l}\text { 3PLRLs company always has an adequate and } \\
\text { widely-covered logistics network (warehouse, DCs, } \\
\text { hubs) to support reverse logistics flows. }\end{array}$ & 3.45 & 0.976 & 0.565 & 0.708 \\
\hline TG2 & $\begin{array}{l}\text { 3PLRLs firms always has up-to-date and adequate } \\
\text { equipment to handle reverse logistics flows. }\end{array}$ & 3.71 & 0.844 & 0.513 & 0.732 \\
\hline TG3 & $\begin{array}{l}\text { 3PLRLs company own an excellent technology } \\
\text { systems and IT staffs to maintain the systems }\end{array}$ & 3.39 & 0.838 & 0.600 & 0.687 \\
\hline TG4 & $\begin{array}{l}\text { 3PLRLs company always provides RL services for } \\
\text { E-commerce platform and electronic documents } \\
\text { (reports, invoices, bills) for reverse logistics service. }\end{array}$ & 3.48 & 0.856 & 0.576 & 0.699 \\
\hline \multicolumn{2}{|c|}{ ES (Eco-sustainability). } & \multicolumn{3}{|c|}{ Cronbach's Alpha: 0.769} & \\
\hline ES1 & $\begin{array}{l}\text { 3PLRLs company always comply with environmental } \\
\text { rules, laws (such as ISO 14000) when executing } \\
\text { reverse logistics service. }\end{array}$ & 3.23 & 0.849 & 0.605 & 0.712 \\
\hline ES2 & $\begin{array}{l}\text { 3PLRLs company } \\
\text { environmentally-friendly } \\
\text { reverse logistics. }\end{array}$ & 3.31 & 1.108 & 0.747 & 0.645 \\
\hline ES3 & $\begin{array}{l}\text { 3PLRLs company always sets official sustainability } \\
\text { initiatives and collaborates with other firms to seek } \\
\text { mutual sustainability goals. }\end{array}$ & 3.71 & 0.958 & 0.192 & 0.830 \\
\hline ES4 & $\begin{array}{l}\text { 3PLRLs company always agrees to incorporate the } \\
\text { provision of eco-sustainability in the reverse logistics } \\
\text { service contract. }\end{array}$ & 2.50 & 1.134 & 0.519 & 0.736 \\
\hline ES5 & $\begin{array}{l}\text { 3PLRLs service provider always investigates and } \\
\text { invests in green energy sources for facilities such as } \\
\text { warehouses, hubs, distribution centers. }\end{array}$ & 3.35 & 1.054 & 0.697 & 0.668 \\
\hline
\end{tabular}

FS3PLRL (Choice of third-party reverse logistics service providers). Mean: 3.39 ; Cronbach's Alpha:0.846 


\begin{tabular}{llllll}
\hline FS3PLRL1 & $\begin{array}{l}\text { My company feels satisfied with the provided service } \\
\text { and will continue to purchase the service from the } \\
\text { 3PLRLs firm }\end{array}$ & 0.923 & 0.615 & 0.835 \\
\hline FS3PLRL2 & It is a good decision to work with the 3PLRLs firm & 3.24 & 0.931 & 0.703 & 0.797 \\
\hline FS3PLRL3 & $\begin{array}{l}\text { I will advocate this 3PLRLs firm to other companies } \\
\text { (suppliers, customers, contractors, etc) }\end{array}$ & 3.44 & 0.86 & 0.821 & 0.745 \\
\hline FS3PLRL4 & $\begin{array}{l}\text { My company will purchases RL services from the } \\
\text { 3PLRLs firm for long-term interval }\end{array}$ & 0.819 & 0.608 & 0.835 \\
\hline
\end{tabular}

(Synthesized by the authors, 2021)

Table 3. Result of Barlett's Test of Sphericity and KMO Measure of Sampling Adequacy for independent variables

\begin{tabular}{ll}
\hline Indicator & Value \\
\hline Kaizer-Meyers-Olkin Measure of Sampling Adequacy & 0.836 \\
\hline Barrtlett's Testing of Sphericity's Significance (Sig.) & 0.000 \\
\hline Variance (Cumulative) & $69.434 \%$ \\
\hline Eigenvalue & 1.623
\end{tabular}

(Synthesized by the authors, 2021)

Table 4. Outcomes of Rotated Component Matrix of independent variables

\begin{tabular}{|c|c|c|c|c|c|c|}
\hline \multirow[t]{2}{*}{ Factor } & \multirow[t]{2}{*}{ Variable } & \multicolumn{5}{|c|}{ Factor loading } \\
\hline & & 1 & 2 & 3 & 4 & 5 \\
\hline \multirow[t]{6}{*}{ Quality of service } & QS6 & 0.871 & & & & \\
\hline & QS5 & 0.869 & & & & \\
\hline & QS3 & 0.865 & & & & \\
\hline & QS1 & 0.830 & & & & \\
\hline & QS2 & 0.800 & & & & \\
\hline & QS7 & 0.669 & & & & \\
\hline \multirow[t]{6}{*}{ Total cost } & TC3 & & 0.829 & & & \\
\hline & TC5 & & 0.808 & & & \\
\hline & TC2 & & 0.807 & & & \\
\hline & TC4 & & 0.745 & & & \\
\hline & TC1 & & 0.662 & & & \\
\hline & TC6 & & 0.649 & & & \\
\hline \multirow[t]{4}{*}{ Credibility } & $\mathrm{RC} 3$ & & & 0.838 & & \\
\hline & $\mathrm{RC} 1$ & & & 0.817 & & \\
\hline & $\mathrm{RC} 2$ & & & 0.789 & & \\
\hline & $\mathrm{RC} 4$ & & & 0.755 & & \\
\hline \multirow[t]{4}{*}{ Eco-sustainability } & ES2 & & & & 0.871 & \\
\hline & ES5 & & & & 0.790 & \\
\hline & ES1 & & & & 0.768 & \\
\hline & ES4 & & & & 0.714 & \\
\hline \multirow{4}{*}{ Tangibility } & TG3 & & & & & 0.784 \\
\hline & TG1 & & & & & 0.747 \\
\hline & TG2 & & & & & 0.646 \\
\hline & TG4 & & & & & 0.609 \\
\hline
\end{tabular}

(Synthesized by the authors, 2021 


\subsection{Multiple linear regression}

As can be noticed from Table 5, the Adjusted R-Squared (Adjusted R2) equals 0.563, meaning that approximately $56.3 \%$ of the variations existed in the dependent variable is explained by independent variables. So as to not encounter first-order autocorrelation, DW must be greater than $\mathrm{dU}$ and smaller than 4- dU. For $\mathrm{N}=200$ and k' $=5$, dU equals 1.725. DW of the author's test which is 2.196 satisfies the above requirements, which indicates that first-order autocorrelation does not exist in the model. With the significance of the test is 0.000 which goes below 0.05 , hence, the linear regression model is valid with the data set collected given $95 \%$ confidence intervals. It is also likely to conclude that multi-collinearity does not happen when VIF of all 5 independent variables are under the threshold of 2 .

It also can be observed from Table 5 that the coefficients of 5 variables Total cost (TC), Quality of service (QS), Credibility (RC), Tangibility (TG) and Eco-sustainability (ES) are $0.214,0.174,0.202,0.243$, 0.283 respectively, with Sig. smaller than 0.05 . All hypotheses are accepted.

\section{GENERAL ASSESSMENT AND RECOMMENDATIONS}

\subsection{General assessment}

\subsubsection{Total cost factor}

Observing the result of all conducted test above especially linear multiple regression, it is feasible to conclude that the "Total cost factor" has a positive influence on the decision of CPG businesses in Hanoi to employ a third-party reverse logistics service provider (3PLRL). Specifically, with the coefficient $\beta=$ 0.214 and the mean of 3.29 , total cost is the third most influencing factor on the decision to choose the right third-party reverse logistics service provider (3PLRL) of CPG firms in Hanoi. This makes sense for two reasons. First, profit is the end goal of every business, while boosting more sales requires a lot of efforts, reducing the cost is considered the top way for firms desiring to improve their bottom line. Second, cost-optimization is the trend in supply chain now and becoming the core target of supply chain department in every company. However, it is important to notice that compared to Tangibility factor and Eco-sustainability factor, Total cost receives less attention. This result is somehow consistent with the result of the research conducted in Vietnam by Le, et.al. (2014) where cost is also not in the first position but still in the top three most important factor when choosing 3PLs.

\subsubsection{Quality of service factor}

The result from conducted tests as well as the multiple linear regression equation allows the authors to conclude that quality of the RL services that 3PLRLs performs will positively influences the decision to select the most suitable 3PLRL for the company. However, as the coefficient $\beta$ only equals 0.174 , the quality of the service from 3PLRL seems not to gain much focus from CPG supply chain manager during the selection decision-making process. This could be explained in this way, expect quality of the service from 3PLRLs is one of the most difficult facet to collect trustworthy data. Most of the data that could be collected is from the advertisement of 3PLRLs which is not subjective. This is also proved in the previous research where quality of service is only considered to be moderately affect the 3PLs selection decisions of client companies. However, it is also noticeable that the mean of this factor is quite high reaching at 3.5 which means a number of companies still considers this factor utmost important one when selecting 3PLs enterprise for them.

Table 5. Linear multiple regression analysis's result

\begin{tabular}{|c|c|c|c|c|c|c|}
\hline & \multicolumn{2}{|c|}{ Unstandardized Coefficients } & \multirow{2}{*}{$\begin{array}{c}\text { Standardized } \\
\text { Coefficients } \\
\qquad \beta \\
\end{array}$} & \multirow[t]{2}{*}{$\mathbf{t}$} & \multirow[t]{2}{*}{ Sig. } & \multirow[t]{2}{*}{ VIF } \\
\hline & $\boldsymbol{\beta}$ & Std. Error & & & & \\
\hline (Constant) & -0.319 & 0.241 & & -1.323 & 0.188 & \\
\hline TC & 0.232 & 0.056 & 0.214 & 4.166 & 0.000 & 1.200 \\
\hline QS & 0.139 & 0.043 & 0.174 & 3.198 & 0.002 & 1.351 \\
\hline $\mathbf{R C}$ & 0.224 & 0.060 & 0.202 & 3.718 & 0.000 & 1.343 \\
\hline TG & 0.265 & 0.060 & 0.243 & 4.392 & 0.000 & 1.396 \\
\hline ES & 0.244 & 0.044 & 0.283 & 5.530 & 0.000 & 1.195 \\
\hline \multicolumn{3}{|c|}{ Durbin-Watson $(D W)=2.196$} & \multicolumn{4}{|c|}{ Significance of F. test $=0.000$} \\
\hline Adjusted R & 563 & & & & & \\
\hline
\end{tabular}

(Synthesized by the authors, 2021) 


\subsubsection{Credibility factor}

Credibility factor is proved to have positive effects on CPG businesses in Hanoi during their third-party reverse logistics service provider (3PLRLs) picking process. Obtaining $\beta=0.202$, Credibility factor is in the fourth position of all 5 factors. Although below the coefficient of Total cost factor, Tangibility and Eco-sustainability, Credibility is still considered major factor deciding whether to choose which 3PLRL. This result has an obvious consistency with the findings in the research of Le, et. al., (2014). In this research Credibility is only ranked in the fifth position over six factors and not much contributes to the selection decisions of companies when choosing 3PLs firms. However, from the result, it is also can see that the mean of this factor is moderate that is 3.45 meaning not few companies still considers this factor somehow important one when selecting 3PLs enterprise for them.

\subsubsection{Tangibility factor}

As can easily be seen from the result of the multiple linear regression that is conducted above, Tangibility factor influence the decision of selecting 3PLRLs of CPG enterprises in Hanoi in a positive direction. Receiving the coefficient at 0.243 and the highest mean among 5 factors at 3.51 , Tangibility is the second most impactful factor on the decision to select the accurate 3PLRLs of CPG companies in Hanoi. In other word, CPG firms in Hanoi would like to contract with a third-party reverse logistics service provider with an adequate and widely covered logistics network, up-to-date and adequate equipment, an excellent technology systems and IT staffs to maintain the systems, etc. This result is different from the research of Rostamzadeh et. al. (2020) where Tangibility is ranked in the fourth position of 5 factors. However, this difference could be understood because this research is conducted in Iran, a country where logistics infrastructure is very modern for a long time. Moreover, Iran is a country that connects the world's west and east, and it has long been strategically important for trade, transportation, and logistics so its logistics tangibility is always developed continuously. In a country like this, tangibility is owned by all 3PLRLs companies, so it is not an important factor to choose 3PLRLs providers. Another research conducted in Vietnam by Le, et.al. (2014) proved Tangibility is top factors influencing this selection decision.

\subsubsection{Eco-sustainability factor}

According to the result of the analysis, Eco-sustainability factor is proved to have the strongest impacts on the decision of CPG businesses in Hanoi to employ 3PLRLs. With the coefficient obtained is 0.283 , this factor is on the highest position among 5 proposed factors. Respondents pay most of their attention to ES5 amongst 4 reliable scales of Eco-sustainability factor with the mean value reaching 3.35 which demands for 3PL service provider to investigate and invests in green energy sources for facilities such as warehouses, hubs, distribution centers. This result is persistent with the prior research of Tajik, et. al. (2013) that Environmental is proved to be the most weighted factor.

It is easy to understand why this is a source of concern: environmental issues are frequently cited as a motivator for reverse logistics. Environmental concerns are increasingly being interested by customers when making purchasing decisions, which has increased consumer awareness of environmentally friendly products, as well as the demand for effective reverse logistics and waste management. Companies often adhere to a set of environmental standards, such as ISO14000. As a result, it is also one of their concerns if their providers comply with any such environmental requirements. Furthermore, corporations typically demand their suppliers to include sustainable power or power-saving facilities into their reverse logistics flow management, owing to customer pressure, brand personality, and the responsibility to optimize the expense of the supply chain function. They also require that sustainability performance measures be included in the contract to assess the result in environmental protection in reverse supply chain flow management.

\subsection{Recommendations}

As mentioned above, this paper aims to find out the factors that affect to decisions of choosing 3PLRLs of CPG enterprises. The results of the research will be very helpful for 3PLRLs firms to enhance their service and capacity to serve and meet the demand of CPG enterprises. The authors have provided some recommendations based on them.

\subsubsection{Recommendations on Eco-sustainability}

First, 3PLRLs should promote more environmentally friendly technology, services for reverse logistics as well as investigates and invests in environmentally friendly equipment, green energy sources for company facilities such as storage warehouses, hubs, distribution centers, fulfillment centers.

Second, 3PLRLs had better strictly following laws and rules about environment issues in running business including ISO 14000.

Finally, a contract with clear and holistic provisions about eco-sustainability issues is demanded for 3PLRLs to make great impressions on their future $\mathrm{CPG}$ clients.

\subsubsection{Recommendations on Tangibility}

First, 3PLRLs company is advised to have an adequate and widely-covered logistics facilities network (warehouse, distribution centers, hubs) so as to best support reverse logistics flows.

Second, in every facility, equipment and vehicles to support reverse logistics activities including transporting trucks, storage pallets, racks, warehouse picking vehicles should be sufficient.

Third, 3PLRLs should also invest into continuously 
upgrade information technology systems and IT employees to keep them running smoothly.

\subsubsection{Recommendations on Total cost}

First, a win-win payment term is a powerful weapon for a 3PLRL in the competition to the reverse logistics contracts with CPG clients in Hanoi.

Second, 3PLRLs that provide clients with a clear price quote for reverse logistics services with no hidden or vague or ambiguous fees will receive more attention.

Finally, promotion program is also a means to trigger CPG companies to use the reverse logistics.

\section{CONCLUSION AND FUTURE RESEARCH ORIENTATIONS}

To identify the factors that influence the decisions of selecting third-party reverse logistics service providers (3PLRLs) of consumer-packaged goods (CPG) enterprises in Hanoi, the authors not only take a deep review on previous local and foreign research discussing the 3PLRLs selection criteria but also has comprehensive consultation with 5 supply chain junior and senior managers from well-known companies in CPG sectors about this research. The authors proposed a research model with 5 main factors including Total cost, Quality of service, Credibility, Tangibility, and Eco-sustainability. The data collected from a survey with 200 qualified responses are then gone through a series of analysis. The results shows that five aforementioned factors, arranged in a sequence as follow, Eco-sustainability $\quad(\beta=0.283), \quad$ Tangibility $(\beta=0.243)$, Total cost $(\beta=0.214)$, Credibility $(\beta=0.202)$, Quality of service $(\beta=0.174)$, have positive impacts on the selection of 3PLRLs at CPG enterprises. Rooms for future research are identifying other factors that may contribute to these decisions, using a more suitable sampling method, conducting in a larger scale of regions and industry, using offline survey to reach more audience and consider using some open-ended questions.

\section{REFERENCES}

[1] Ayvaz, B., Bolat, B. and Aydın, N., (2015), "Stochastic reverse logistics network design for waste of electrical and electronic equipment", Resources, Conservation and Recycling, 104, pp.391-404.

[2] Bulut, e., Deran, a., (2008), "Reverse logistics and its impacts on company's cost management", Ekonomik Yaklasim, 19(Special), p.325.

[3] Coşkun, A. et. al, (2017), "Reverse Logistics, Its Relationship with Cost and Sustainability, Its Inclusion in Curriculum", Journal of Educational and Instructional Studies in the world, Vol. 7, Issue 4, pp.96-106.

[4] Council of Supply Chain Management Professionals. [online] Available at: <https://cscmp.org $>$ [Accessed 5 May 2021].

[5] de Mello Bandeira, R., de Brito Mello, L. and de Paula Fontainhas Bandeira, A., (2011), "Logistics outsourcing decision making process: a case study in an engine manufacturer", On the proceedings of XVII international conference on industrial engineering and operations management Technological Innovation and Intellectual Property: Production Engineering Challenges in Brazil Consolidation in the World Economic Scenario. Belo Horizonte, Brazil, 04 to 07 October - 2011 .

[6] Global Customer Packaged Goods (CPG) Market Size, Shares, Value, and Competitive Landscape 2024. [online] Available at: $<$ https:/www.marketwatch.com/story/global-consumerpackaged-goods-cpg-logistics-market-size-share-value-a nd-competitive-landscape-2020-2021-04-12> [Accessed 1 June 2021].

[7] Govindan, D. K., Pokharel, S., \& Sasikumar, P. (2009), "A hybrid approach using ISM and Fuzzy topsis for the selection of reverse logistics provider", Resources, Conservation and Recycling, 54, 28-36.

[8] Govindan, K., Palaniappan, M., Zhu, Q., Kannan, D., (2012), "Analysis of third-party reverse logistics provider using interpretive structural modeling", Int. J. Production Economics, 140 (2012) 204-211.

[9] Gunasekaran, A., Patel, C., Tirtiroglu, E. (2001), "Performance measures and metrics in a supply chain environment", International Journal of Operations \& Production Management, 21(1/2), pp. 71-87.

[10] Hair, J. F., Sarstedt, M., Hopkins, L., Kuppelwiser, V., (2014), "Partial least squares structure equation modeling (PLS-SEM): An emerging tool in business research", European Business Review, Vol. 26, Issue 2.

[11] Le, B., Tran, C., Dang, T., (2014), "The main criteria impacting the logistics service provider selection in HCM city Vietnam", Economic Development Journal ,285, p. 111-128.

[12] O'Neill, M. and Palmer, A., (2003), “An exploratory study of the effects of experience on consumer perceptions of the service quality construct", Managing Service Quality: An International Journal, 13(3), pp.187-196.

[13] Rostamzadeh, R., Esmaeili, A., Sivilevičius, H. and Nobard, H., (2020). "A fuzzy decision-making approach for evaluation and selection of third-party reverse logistics provider using fuzzy aras", Transport, 35(6), pp.635-657.

[14] Statista Infographics. 2021. Infographic: Worst Plastic Polluters in 2020. [online] Available at: $<$ https://www.statista.com/chart/23720/worst-polluting companies/> [Accessed 1 May 2021].

[15] Tajik, G., Azadnia, A. H., Azanizawati Ma'aram, 
Hassan, S. (2013), “A Hybrid Fuzzy MCDM Approach for Sustainable Third-Party Reverse Logistics Provider Selection", Advanced Material Research, Vol. 845, pp.521-526.

[16] Tsai, M., Lai, K., Lloyd, A. and Lin, H., (2012), "The dark side of logistics outsourcing Unraveling the potential risks leading to failed relationships", Transportation Research Part E: Logistics and Transportation Review, 48(1).

[17] Wollenhaupt, G., 2021. Logistics: To insource or outsource? [online] Supply Chain Dive. Available at: $<$ https://www.supplychaindive.com/news/logistics insource outsource/571612/> [Accessed 05 May 2021].

[18] World Bank. (2021), "International Development, Poverty, \& Sustainability", [online] Available at: $<$ https://www.worldbank.org/en/home $>$ [Accessed May 2021].

[19] Zarbakhshnia, N., Soleimani, H., Ghaderi, H., (2018), "Sustainable Third-Party Reverse Logistics Provider Evaluation and Selection Using Fuzzy SWARA and Developed Fuzzy COPRAS in the Presence of Risk Criteria", Applied Soft Computing, 65 (2018) 307-319. 